\title{
SEBARAN LOGAM BERAT TERLARUT DAN TERENDAPKAN DI PERAIRAN TELUK JAKARTA PADA BULAN SEPTEMBER 2014
}

\author{
DISTRIBUTION HEAVY METAL IN WATER AND SEDIMENT \\ IN THE JAKARTA BAY AT SEPTEMBER 2014
}

\author{
Anma Hari Kusuma ${ }^{1}$, Tri Prartono ${ }^{2}$, Agus Soleh Atmadipoera ${ }^{2}$, Taslim Arifin ${ }^{3}$ \\ ${ }^{1}$ Program Studi Ilmu Kelautan, Sekolah Pascasarjana dan Staf di Kemenkomaritim \\ ${ }^{2}$ Departemen Ilmu dan Teknologi Kelautan \\ ${ }^{3}$ Peneliti Pusat Penelitian dan Pengembangan Sumberdaya Laut dan Pesisir, Balitbang-KP \\ Korespondensi : srohm4n@gmail.com
}

\begin{abstract}
Jakarta Bay is a crowded area with many activities so that a gathering place for pollutants from the land that is transported through the 13 rivers that flow in Jakarta. The purpose of this research is to explain the process and sources of heavy metal with to compare distribution profile heavy metal in water and sediment in Transitional Season I and Transitional Season II in the Jakarta Bay. The research heavy metal in water and sediment in Jakarta Bay was conducted in September 2014. Analysis of heavy metal in water and sediment use procedure (APHA 2012). The results showed hydro-oceanographic condition in the Jakarta Bay for current velocity range from 0.002-0.028 $\mathrm{m} / \mathrm{s}$ to wards west and southwest, the wind speed range 4-17 knot blowing to the southwest and tidal tipe of single of riding the tide of $0,84 \mathrm{~m}$. The temperature range $28.9-30.2{ }^{\circ} \mathrm{C}$, salinity range $29.5-30.6 \mathrm{psu}$, acidity $(\mathrm{pH})$ range $7.80-8.17$ and suspended solid (TSS) range 25-68 mg/l. Heavy metals in water for Pb range 0.006-0.016 ppm, Cd range 0.001-0.003 $\mathrm{ppm}, \mathrm{Cu}$ range from 0.001-0.005 ppm, Ni range 0.001-0.016 ppm and Zn range 0.003-0.097 ppm. Heavy metal in sediment for $\mathrm{Pb}$ range $24.86-59.32 \mathrm{ppm}$, Cd range 0.32-3.49 ppm, Cu range 11.42-67 ppm, Ni range 19.80-39.85 ppm and $\mathrm{Zn}$ range 26.14 to $241.01 \mathrm{ppm}$. Distribution of heavy metal in water and sediment to indicated the sources of heavy metal in the Jakarta Bay largely derived input material from the terrestrial.
\end{abstract}

Keywords: disolved heavy metal, heavy metal in sediment, Jakarta Bay, physico-chemical

\begin{abstract}
ABSTRAK
Teluk Jakarta merupakan kawasan padat dengan berbagai aktivitas sehingga menjadi tempat berkumpulnya polutan dari daratan yang ditransport melalui 13 sungai yang mengalir di wilayah DKI Jakarta. Tujuan dari penelitian ini adalah menjelaskan proses dan sumber logam berat melalui perbandingan profil sebaran logam berat terlarut dan terendapkan pada bulan September di Perairan Teluk Jakarta. Penelitian logam berat terlarut dan terendapkan di perairan Teluk Jakarta telah dilakukan pada bulan September 2014. Analisis logam berat terlarut dan sedimen mengikuti prosedur (APHA 2012). Hasil penelitian menunjukkan kondisi fisika-kimia perairan Teluk Jakarta untuk suhu berkisar 28.9-30.2 ${ }^{\circ} \mathrm{C}$, salinitas berkisar 29.5-30.6 psu, derajat keasaman $(\mathrm{pH})$ berkisar 7.80-8.17 dan partikel tersuspensi (TSS) berkisar 25-68 mg/l. Logam berat terlarut untuk Pb berkisar 0.006-0.016 ppm, Cd berkisar 0.001-0.003 ppm, Cu berkisar 0.001-0.005 ppm, Ni berkisar 0.001-0.016 ppm dan Zn berkisar 0.003-0.097 ppm. Logam berat sedimen untuk Pb berkisar 24.86-59.32 ppm, Cd berkisar 0.32-3.49 ppm, Cu berkisar 11.42-67 ppm, Ni berkisar 19.80-39.85 ppm dan Zn berkisar 26.14-241.01 ppm. Sebaran logam berat terlarut yang diperkuat dengan sebaran logam berat dalam sedimen mengindikasikan sumber logam berat di perairan Teluk Jakarta sebagian besar berasal dari input materi dari daratan.
\end{abstract}

Kata kunci: fisika-kimia, logam berat sedimen, logam berat terlarut, Teluk Jakarta 


\section{PENDAHULUAN}

Teluk Jakarta merupakan kawasan padat dengan berbagai aktivitas sehingga menjadi tempat berkumpulnya polutan dari daratan yang ditranspor secara langsung maupun tidak langsung melalui 13 sistem sungai yang mengalir di wilayah DKI Jakarta. Sumber polutan tersebut berasal dari aktivitas antropogenik yang tinggi seperti limbah kegiatan industri, pelabuhan, perikanan dan sampah. Limbah tersebut mengandung materi yang bersifat racun dan berbahaya. Salah satu materi tersebut adalah logam berat. Logam berat merupakan elemen kimia dengan berat massa atom sebesar $5 \mathrm{gr} / \mathrm{cm}^{3}$ (Buffle \& Vitre 1994). Pada dasarnya logam berat termasuk ke dalam golongan logam dengan kriteria yang sama dengan logam lainnya. Perbedaanya terletak pada pengaruh yang dihasilkan, logam berat mampu membentuk ikatan kompleks saat masuk ke dalam tubuh organisme (Palar 1994). Banyak persoalan yang terjadi akibat yang di timbulkan oleh polutan logam berat, mulai dari matinya ratusan ikan, udang dan rajungan sampai dengan ribuan nelayan yang semakin miskin hidupnya karena hilangnya mata pencaharian mereka dan juga masalah kesehatan yang diderita oleh masyarakat di sekitar Teluk Jakarta. Berbagai penelitian mengenai logam telah banyak dilakukan, mulai dari logam berat dalam bentuk terlarut (Lestari dan Edward 2004), dalam organisme (Riyani 2010.) dan dalam sedimen (Rochyatun dan Razak 2007) yang menggambarkan konsentrasi logam berat masih sangat bervariasi dari waktu ke waktu dimana penelitian sebelumnya masih berkisar tentang pencemaran dan konsentrasi namun masih bersifat hanya menduga mengenai sumber dari logam berat.

Penelitian ini memberikan penjelasan lebih lanjut terhadap pola sebaran logam berat dalam air dan sedimen yang berkaitan dengan pasokan input materi dan pengaruhnya terhadap kondisi perairan Teluk Jakarta. Tujuan dari penelitian ini adalahmenjelaskan proses dan sumberlogam berat melalui perbandingan profil sebaran logam berat terlarut dan terendapkan pada Musim Peralihan I dan Musim Peralihan II di Perairan Teluk Jakarta. Hasil dari penelitian ini diharapkan diharapkan dapat bermanfaat untuk menambah informasi mengenai sebaran logam berat dalam air dan sedimen pada Musim Peralihan I dan Musim Peralihan II di perairan Teluk Jakarta, sehingga dapat digunakan bagi perencanaan, pengelolaan dan pengkajian wilayah pesisir secara berkelanjutan oleh pihak yang berkepentingan.

\section{METODE PENELITIAN}

Penelitian ini dilakukan dari bulan September sampai Desember 2014. Waktu dan lokasi pengambilan sampel dilakukan pada tanggal 10 September 2014 di perairan Teluk Jakarta (Gambar 1). Stasiun penelitian terdiri dari 15 titik yang tersebar mewakili bagian wilayah Barat, Tengah dan Timur. Analisis logam berat terlarut dan sedimen dilakukan pada tanggal 13 September 2014 di Laboratorium Produktivitas Lingkungan Departemen MSP-IPB sedangkan pengolahan data mengenai logam berat dilakukan dari bulan Oktober-Desember di Laboratorium Oseanografi Kimiawi Departemen ITK-IPB.

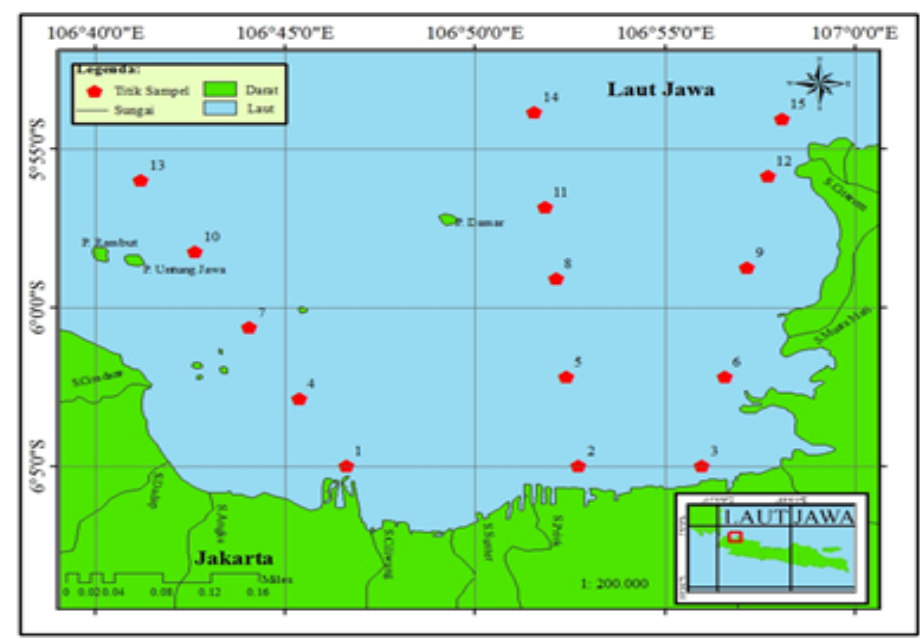

Gambar 1. Peta lokasi penelitian dan titik pengamatan di perairan Teluk Jakarta 


\section{Pengukuran parameter perairan}

Pengukuran mengenai fisika-kimia perairan yang parameter dilakukan dilapangan meliputi suhu, salinitas, dan derajat keasaman $(\mathrm{pH})$ dilakukan menggunakan alat TOAA U 50 Series sedangkan logam berat dilakukan pengambilan contoh air dan sedimen untuk dianalisis di laboratorium melalui penjelasan sebgai berikut.

\section{Pengambilan contoh air laut}

Contoh air laut diambil menggunakan Van Dorn Water Sampler dengan volume 2 liter yang terbuat dari bahan Poly Vinyl Clorida (PVC). Contoh air laut dimasukkan ke dalam botol polyetilen bersih sesuai standar (APHA 2012) dengan volume 1 liter dan disimpan di dalam kotak es selama proses transportasi menuju laboratorium untuk dilakukan analisis.

\section{Pengambilan contoh sedimen}

Contoh sedimen diambil menggunakan Van Veen Grab. Contoh sedimen dimasukkan ke dalam botol polyetilen bersih sesuai standar (APHA 2012) dengan volume 250 $\mathrm{ml}$ dan disimpan di dalam kotak es selama proses transportasi menuju laboratorium untuk dilakukan analisis.

\section{Analisis partikel tersuspensi (TSS)}

Analisis partikel tersuspensi mengikuti prosedur APHA (2012) yang secara singkat di uraikan sebagai berikut. Contoh air laut sebanyak $100 \mathrm{ml}$ disaring menggunakan filter selulosa dengan ukuran 0.45 (bersih, kering dan ditimbang berat awal). Filter selulosa hasil penyaringan selanjutnya dikeringkan dalam oven $103-105^{\circ} \mathrm{C}$ selama 1 jam. Filter selulosa didinginkan dalam desikator dan ditimbang untuk didapatkan berat akhir.

\section{Analisis logam berat terlarut}

Analisis logam berat terlarut mengikuti prosedur APHA (2012) yang secara singkat diuraikan sebagai berikut. Contoh air laut sebanyak $250 \mathrm{ml}$ disaring menggunakan filter selulosa dengan ukuran $0.45 \mu \mathrm{m}$ dan selanjutnya ditambahkan asam nitrat $\left(\mathrm{HNO}_{3}\right)$ pekat sampai $\mathrm{pH}<2$ lalu diekstraksi dengan $5 \mathrm{ml}$ APDC dan $25 \mathrm{ml}$ MIBK. Hasil ekstraksi dalam fase organik selanjutnya dilarutkan kembali dengan menambahkan $2 \mathrm{ml}$ asam nitat $\left(\mathrm{HNO}_{3}\right)$ pekat sehingga terbentuk ion logam yang larut dalam fase air. Kadar logam berat di ukur nilainya dengan mengguankan AAS Pin Aacle $900 \mathrm{H}$ dengan deteksi limit 0.001 ppm.

\section{Analisis logam berat terendapkan}

Analisis logam berat terendapkan prosedur APHA (2012) yang secara singkat diuraikan sebagai berikut. Contoh sedimen sebanyak 50 gr dikeringkan terlebih dahulu dalam oven pada suhu $103-105{ }^{\circ} \mathrm{C}$ selama 1 hari. Contoh sedimen didinginkan pada desikator dan ditimbang sebanyak $1 \mathrm{~g}$. Contoh sedimen dimasukkan ke dalam gelas beker kemudian ditambahkan $5 \mathrm{ml} \mathrm{HNO}_{3}$ dan dipanaskan diatas penangas hingga volume berkurang menjadi $1 \mathrm{ml}$. Contoh sedimen ditambahkan lagi $10 \mathrm{ml} \mathrm{HNO}_{3}$ dan $10 \mathrm{ml} \mathrm{HClO}_{4}$ hingga menjadi larutan. Larutan dipanaskan kembali hingga volume berkurang menjadi $5 \mathrm{ml}$ sampai tidak ada asap putih yang muncul. Larutan didinginkan dan disaring dengan filter selulosa dengan ukuran $0.45 \mu \mathrm{m}$ kemudian dibilas dengan akuades sampai volume 100 ml. Larutan dimasukkan ke dalam botol sampel dan diinjeksi menggunakan AAS Pin Aacle $900 \mathrm{H}$ dengan deteksi limit 0,001 ppm.

\section{Analisis data}

Analisis data suhu, salinitas, derajat keasaman $(\mathrm{pH})$, partikel tersuspensi (TSS), logam berat terlarut dan terendapkan dilakukan dengan melihat pola sebaran menggunakan Surfer 8.0.

\section{HASIL DAN PEMBAHASAN}

\section{Kondisi fisika-kimia perairan Teluk Jakarta}

Hasil pengamatan suhu, salinitas, derajat keasaman $(\mathrm{pH})$ dan partikel tersuspensi (TSS) permukaan perairan menunjukkan nilai yang bervariasi dan umumnya hanya sedikit berbeda dari beberapa hasil penelitian sebelumnya. Suhu permukaan perairan berkisar antara 28.90$30.20{ }^{\circ} \mathrm{C}$ dengan rata-rata sebesar $29.30{ }^{\circ} \mathrm{C}$ (Gambar 2). Hasil pengamatan sebelumnya mengatakan suhu perairan Teluk Jakarta berkisar 28.90-31.20 ${ }^{\circ} \mathrm{C}$ (Illahude 1995; Wiliam et al. 2000; Paonganan et al. 2005 dan Hadikusumah 2008). Salinitas 
permukaan perairan berkisar 29.50-30.60 psu dengan rata-rata sebesar $30.20 \%$ (Gambar 3). Hasil pengamatan sebelumnya mengatakan salinitas perairan Teluk Jakarta berkisar 22-32.40 \% (Praseno dan Kastoro 1979; Illahude 1995; Mezuan 2007; Sutisna 2007 \& Hadikusumah 2008). Derajat keasaman $(\mathrm{pH})$ permukaan perairan berkisar 7.80-8.17 dengan rata-rata sebesar 8.02 (Gambar 4). Hasil pengamatan sebelumnya mengatakan derajat keasaman $(\mathrm{pH})$ perairan Teluk Jakarta berkisar 6.508.10 (Praseno dan Kastoro 1979; Wiliam et al. 2000; Paonganan et al. 2005; Sutisna 2007 \& BPLHD 2010). Partikel tersuspensi (TSS) permukaan perairan berkisar 25-68 $\mathrm{mg} / 1$ dengan rata-rata sebesar $54.26 \mathrm{mg} / 1$ (Gambar 5). Hasil pengamatan sebelumnya mengatakan partikel tersuspensi (TSS) perairan Teluk Jakarta berkisar 5-45.20 mg/1 (Pemda DKI 1999; Mezuan 2007 \& Sutisna 2007). Secara umum hasil penelitian menunjukkan bahwa kontribusi input masukan dari daratan yang dibawa dari melalui sungai atau drainase yang masuk ke wilayah pesisir sangat mempengaruhi kondisi perairan Teluk Jakarta terutama suhu, salinitas, derajat keasaman $(\mathrm{pH})$ dan partikel tersuspensi (TSS). Kondisi ini terlihat dari pola sebaran salinitas dan derajat keasaman $(\mathrm{pH})$ yang terlihat rendah sedangkan suhu dan partikel tersuspensi (TSS) yang terlihat tinggi di wilayah pesisir. Hal ini membuktikan bahwa kondisi perairan Teluk Jakarta sebagian besar dipengaruhi oleh aktivitas dari daratan.

\section{Sebaran logam berat terlarut perairan Teluk Jakarta}

Hasil pengamatan $\mathrm{Pb}, \mathrm{Cd}, \mathrm{Cu}$, Ni dan $\mathrm{Zn}$ terlarut permukaan perairan menunjukkan nilai yang bervariasi dan umumnya hanya sedikit berbeda dari beberapa hasil penelitian sebelumnya. $\mathrm{Pb}$ terlarut perairan berkisar antara 0.006-0.016 ppm dengan rata-rata sebesar $0.011 \mathrm{ppm}$ (Gambar 9). Hasil pengamatan sebelumnya mengatakan $\mathrm{Pb}$ terlarut perairan Teluk Jakarta berkisar 0.001-0.012 ppm (Arifin et al. 2003; Arifin 2004; Lestari \& Edward 2004; Razak 2004; Razak \& Muchtar 2004; Mulyawan 2005 dan Sanusi et al. 2005).Cd terlarut perairan berkisar antara 0.001-0.003 ppm dengan rata-rata sebesar $0.002 \mathrm{ppm}$ (Gambar 10). Hasil pengamatan sebelumnya mengatakan Cd terlarut perairan Teluk Jakarta berkisar 0.018-0.080 ppm (BAPEDAL 1993; Mulyawan 2005; Sanusi et al. 2005 dan
Sutisna 2007). Cu terlarut perairan berkisar antara 0.001-0.005 ppm dengan rata-rata sebesar 0.002 ppm (Gambar 11). Hasil pengamatan sebelumnya mengatakan $\mathrm{Cu}$ terlarut perairan Teluk Jakarta berkisar 0.001-0.036 ppm (Ismail dan Wasilun 1986; Arifin et al. 2003; Arifin 2004 dan Razak 2004). Ni terlarut perairan berkisar antara 0.001-0.016 ppm dengan rata-rata sebesar 0.006 ppm (Gambar 12). Hasil pengamatan sebelumnya mengatakan Ni terlarut perairan Teluk Jakarta berkisar 0.001-0.045 ppm (Arifin et al. 2003; Arifin 2004 dan Lestari dan Edward 2004). Zn terlarut perairan berkisar antara 0.003-0.097 ppm dengan rata-rata sebesar $0.044 \mathrm{ppm}$ (Gambar 13). Hasil pengamatan sebelumnya mengatakan $\mathrm{Zn}$ terlarut perairan Teluk Jakarta berkisar 0.001-0.041 ppm (Ismail dan Wasilun 1986; Wiliam et al. 2000; Arifin et al. 2003; Arifin 2004; Razak 2004 \& Hamzah dan Setiawan 2010). Nilai konsentrasi $\mathrm{Pb}, \mathrm{Cd}, \mathrm{Cu}, \mathrm{Ni}$ dan $\mathrm{Zn}$ terlarut perairan Teluk Jakarta cenderung meningkat tetapi tidak terlalu signifikan dibandingkan dengan penelitian yang telah dilakukan sebelumnya. Konsentrasi $\mathrm{Pb}, \mathrm{Cd}$, $\mathrm{Cd}$, Ni dan $\mathrm{Zn}$ terlarut pada penelitian ini relatif lebih tinggi dibandingkan dengan penelitian sebelumnya.

Sebaran $\mathrm{Pb}, \mathrm{Cu}$ dan $\mathrm{Zn}$ terlarut perairan pada lokasi penelitian terlihat tinggi di pesisir dan semakin rendah menuju ke arah laut namun kondisi sebaliknya $\mathrm{Cd}$ dan $\mathrm{Ni}$ terlarut terlihat rendah di pesisir dan semakin tinggi menuju ke arah laut. Sebaran $\mathrm{Pb}, \mathrm{Cu}$ dan $\mathrm{Zn}$ terlarut perairan pada lokasi penelitian yang terlihat tinggi di pesisir di duga sumber logam berat untuk $\mathrm{Pb}, \mathrm{Cu}$ dan $\mathrm{Zn}$ berasal dari daratan sedangkan kondisi sebaran $\mathrm{Cd}$ dan $\mathrm{Ni}$ terlarut yang terlihat semakin tinggi menuju ke arah laut di duga sumber logam berat untuk $\mathrm{Cd}$ dan Ni berasal dari laut itu sendiri.

Sebaran logam berat $\mathrm{Pb}, \mathrm{Cd}, \mathrm{Cu}, \mathrm{Ni}$ dan $\mathrm{Zn}$ terlarut belum mampu menjelaskan secara rinci mengenai proses dan sumber logam berat di perairan Teluk Jakarta. Hal ini karena kondisi permukaan laut bersifat dinamis sehingga banyak terjadi gangguan akibat pengaruh dari fisika-kimia perairan. Secara umum membuktikan bahwa sebaran logam berat $\mathrm{Pb}, \mathrm{Cd}, \mathrm{Cu}$, $\mathrm{Ni}$ dan $\mathrm{Zn}$ terlarut di perairan Teluk Jakarta sangat dipengaruhi oleh kondisi fisika-kimia perairan.

\section{Sebaran logam berat terendapkan Perairan Teluk Jakarta}

Hasil pengamatan $\mathrm{Pb}, \mathrm{Cd}, \mathrm{Cu}$, Ni dan 
Zn terendapkan menunjukkan nilai yang bervariasi dan umumnya hanya sedikit berbeda dari beberapa hasil penelitian sebelumnya. $\mathrm{Pb}$ terendapkan perairan berkisar antara 24.86-59.32 ppm dengan rata-rata sebesar $38.53 \mathrm{ppm}$ (Gambar 14). Hasil pengamatan sebelumnya mengatakan $\mathrm{Pb}$ terendapkan perairan Teluk Jakarta berkisar 10.90-176.50 ppm (Hutagalung 1994; Hutagalung 1996; Wiliam et al. 2000; Arifin et al. 2003; Arifin 2004; Razak 2004; Muhajir et al. 2004; Sutisna 2007; Rochyatun \& Rozak 2007 dan Arifin \& Fadlina 2009 dan Hamzah \& Setiawan 2010). $\mathrm{Cd}$ terendapkan perairan berkisar antara 0.32-3.49 ppm dengan rata-rata sebesar $1.37 \mathrm{ppm}$ (Gambar 15). Hasil pengamatan sebelumnya mengatakan $\mathrm{Cd}$ terendapkan perairan Teluk Jakarta berkisar 0.12-2.66 ppm (Hutagalung 1994; Hutagalung 1996; Arifin et al. 2003 dan Mulyawan 2005). $\mathrm{Cu}$ teredapkan berkisar antara 11.42-67 ppm dengan rata-rata sebesar 33.13 ppm (Gambar 16). Hasil pengamatan sebelumnya mengatakan $\mathrm{Cu}$ terendapkan perairan Teluk Jakarta berkisar 7.2-186.8 ppm (Hutagalung 1994; Hutagalung 1996; Arifin et al. 2003; Arifin \& Fadlina 2009 dan Hamzah \& Setiawan 2010). Ni terendapkan perairan berkisar antara 19.80-39.85 ppm dengan rata-rata sebesar $26.72 \mathrm{ppm}$ (Gambar 17). Hasil pengamatan sebelumnya mengatakan $\mathrm{Ni}$ terendapkan perairan Teluk Jakarta berkisar 2.94-35.38 ppm (Hutagalung 1996; Muhajir et al. 2004 dan Rochyatun \& Rozak 2007). Zn terendapkan perairan berkisar antara 26.14-241.01 ppm dengan rata-rata sebesar 109.01 ppm (Gambar 18). Hasil pengamatan sebelumnya mengatakan $\mathrm{Zn}$ terendapkan perairan Teluk Jakarta berkisar 51.9-533.5 ppm (Arifin et al. 2003; Razak 2004; Rochyatun \& Rozak 2007 dan Hamzah $\&$ Setiawan 2010). Nilai konsentrasi $\mathrm{Pb}, \mathrm{Cd}$, $\mathrm{Cu}$, Ni dan $\mathrm{Zn}$ terendapkan perairan Teluk Jakarta cenderung meningkat tetapi tidak terlalu signifikan dari penelitian yang telah dilakukan sebelumnya. Konsentrasi $\mathrm{Pb}, \mathrm{Cd}$, $\mathrm{Cd}$, Ni dan $\mathrm{Zn}$ terendapkan pada penelitian ini relatif lebih tinggi dibandingkan dengan penelitian sebelumnya.

Sebaran $\mathrm{Pb}, \mathrm{Cu}$ dan $\mathrm{Zn}$ terendapakan perairan pada lokasi penelitian terlihat tinggi di pesisir dan semakin rendah menuju ke arah laut namun kondisi sebaliknya menunjukkan sebaran $\mathrm{Cd}$ dan $\mathrm{Ni}$ terendapkan terlihat rendah di pesisir dan semakin tinggi menuju ke arah laut. Sebaran $\mathrm{Pb}, \mathrm{Cu}$ dan $\mathrm{Zn}$ terendapkan perairan pada lokasi penelitian yang terlihat tinggi di pesisir semakin kuat menunjukkan sumber logam berat untuk $\mathrm{Pb}, \mathrm{Cu}$ dan $\mathrm{Zn}$ berasal dari daratan sedangkan kondisi sebaran $\mathrm{Cd}$ dan $\mathrm{Ni}$ terendapkan yang terlihat semakin tinggi menuju ke arah laut sumber logam berat untuk $\mathrm{Cd}$ dan $\mathrm{Ni}$ berasal dari laut itu sendiri. Konsentrasi $\mathrm{Cd}$ terendapkan yang terlihat tinggi di bagian Barat diduga sumber logam $\mathrm{Cd}$ sebagian besar berasal dari wilayah Tangerang dan Banten. Selain itu konsentrasi Cd terendapkan sangat kecil sehingga mudah hilang dan lepas ke kolom air dan langsung terbawa arus. Konsentrasi $\mathrm{Ni}$ terendapkan yang semakin tinggi menuju ke arah laut menunjukkan sumber logam berat berasal dari laut seperti dari aktivitas kapal-kapal yang sangat besar yang tidak melakukan bongkar muat di kawasar pesisir melainkan melakukan bongkar muat di tengah laut.

Secara umum penelitian ini menunjukkan bahwa pola sebaran logam berat terendapkan lebih mampu mengindikasikan sumbernya dibandingkan logam berat yang ada di air. Hal ini karena permukaan laut bersifat dinamis sehingga banyak terjadi gangguan dari fisika-kimia perairan yang bersifat kompleks seperti adeksi-difusi, adsorsi-desropsi dan deposisi-disolusi sedangkan sedimen bersifat relatif konstan. Potensi sumber logam berat sebagian besar berasal dari daratan seperti aktivitas pelabuhan dan industri (Rochyatun \& Razak 2007 dan Arifin \& Fadhlina 2009). Kegiatan aktivitas di pelabuhan seperti pengecetan kapal, pembuangan air ballast, docking kapal dan pengisian bahan bakar mampu memberi kontribusi logam berat ke perairan. Selain itu, adanya berbagai industri di kawasan pesisir seperti pabrik kimia, cat, tekstil dan batu baterai diperkirakan membuang limbahnya melalui sungai atau drainase melewati muara menuju Teluk Jakarta. 


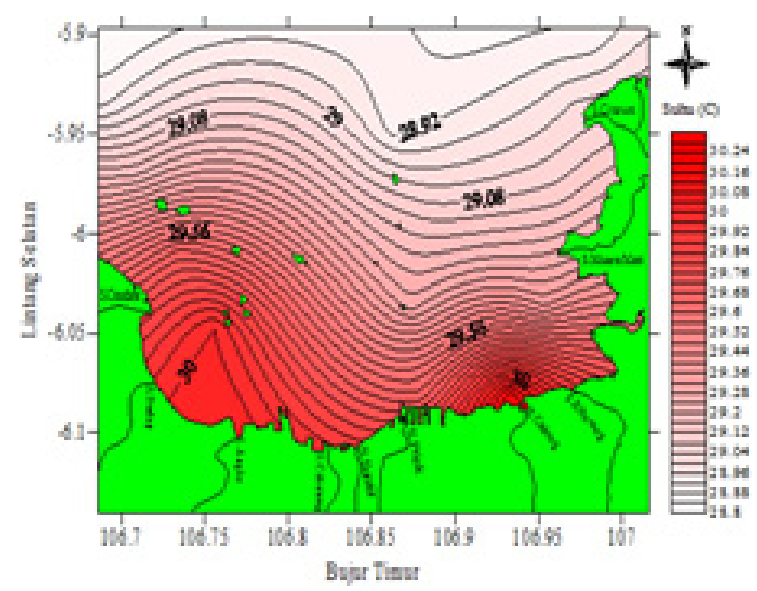

Gambar 2. Sebaran suhu permukaan

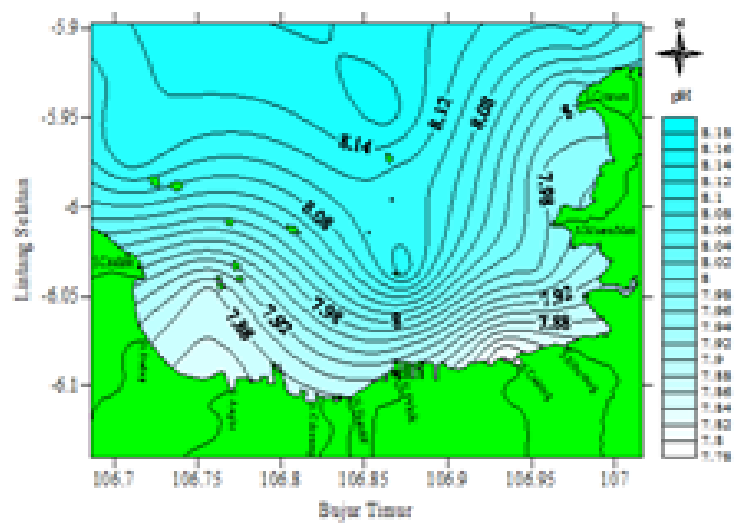

Gambar 4. Sebaran $\mathrm{pH}$ permukaan

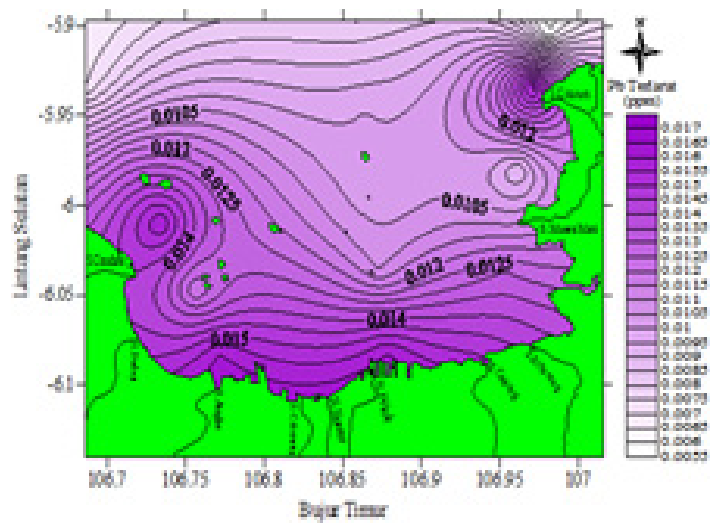

Gambar 6. Sebaran kadmium $(\mathrm{Pb})$ terlarut

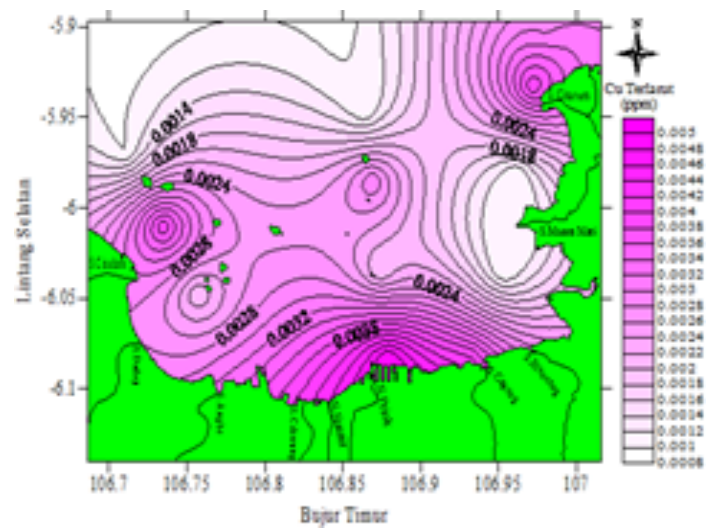

Gambar 8. Sebaran tembaga $(\mathrm{Cu})$ terlarut

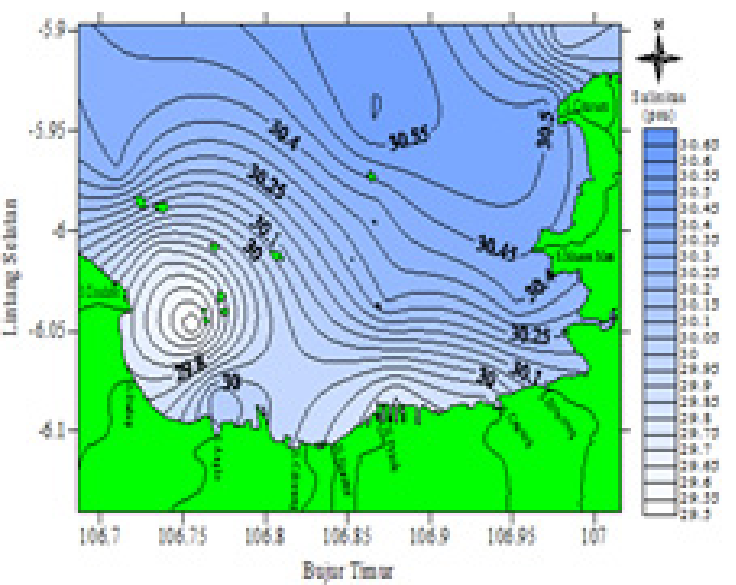

Gambar 3. Sebaran salinitas permukaan

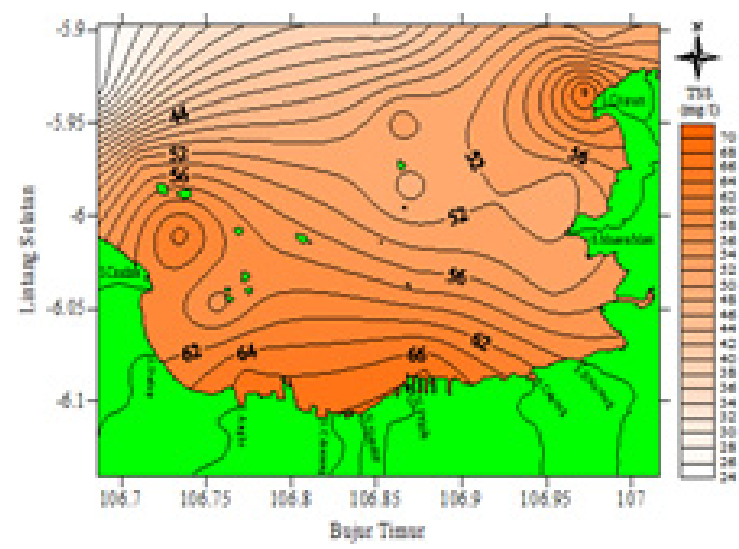

Gambar 5. Sebaran TSS permukaan

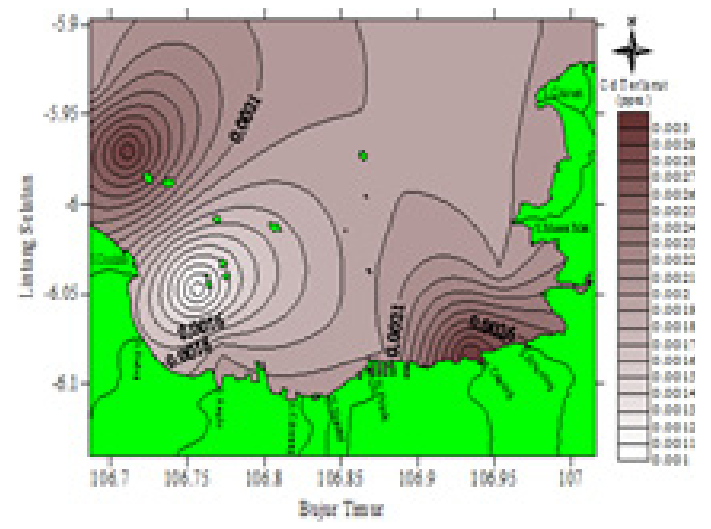

Gambar 7. Sebaran kadmium (Cd) terlarut

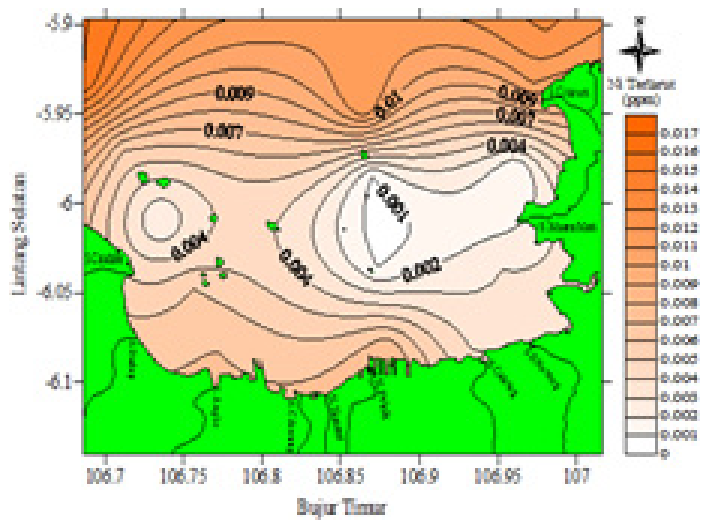

Gambar 9. Sebaran nikel (Ni) terlarut 


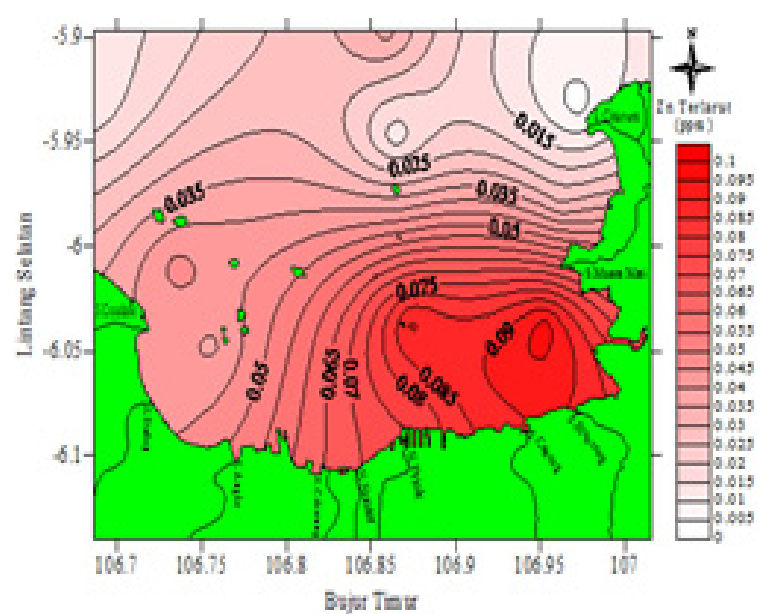

Gambar 10. Sebaran seng (Zn) terlarut

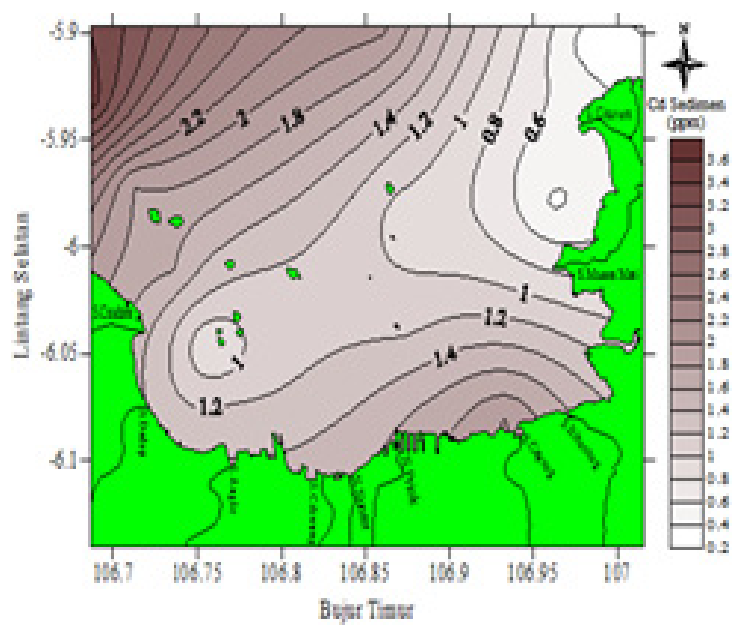

Gambar 12. Sebaran kadmium (Cd) terendapkan

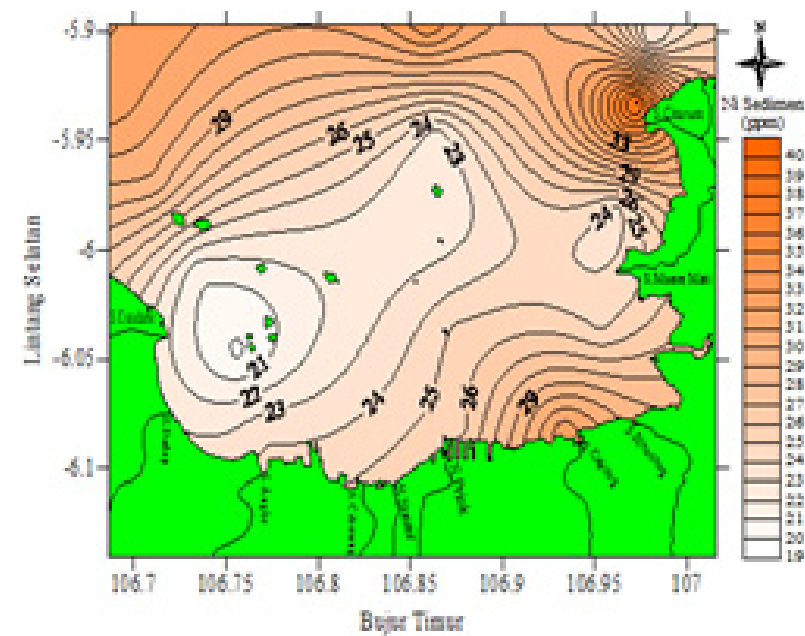

Gambar 14. Sebaran nikel (Ni) terendapkan

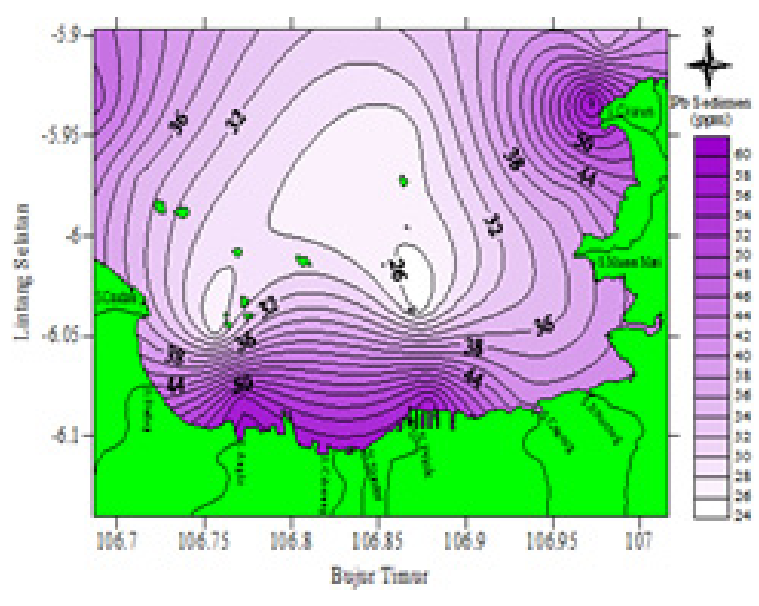

Gambar 11. Sebaran timbal $(\mathrm{Pb})$ terendapkan

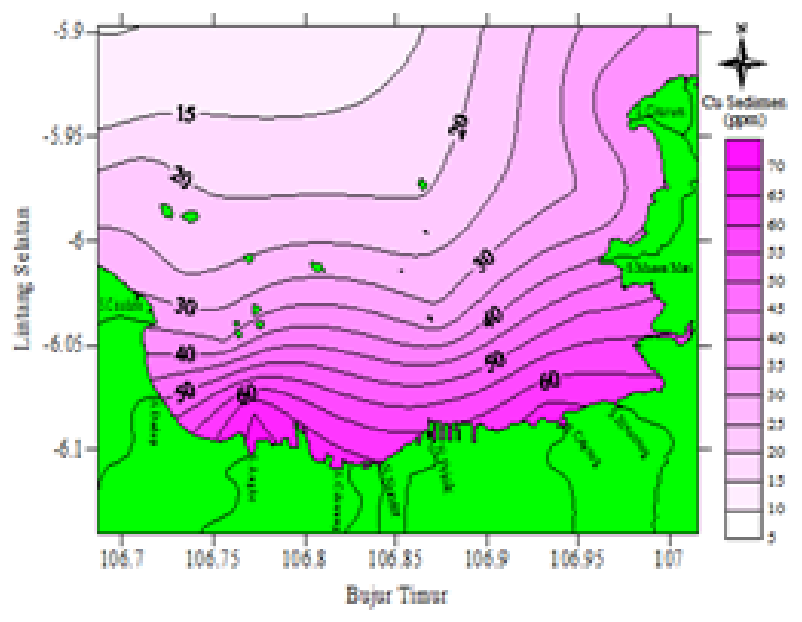

Gambar 13. Sebaran tembaga $(\mathrm{Cu})$ terendapkan

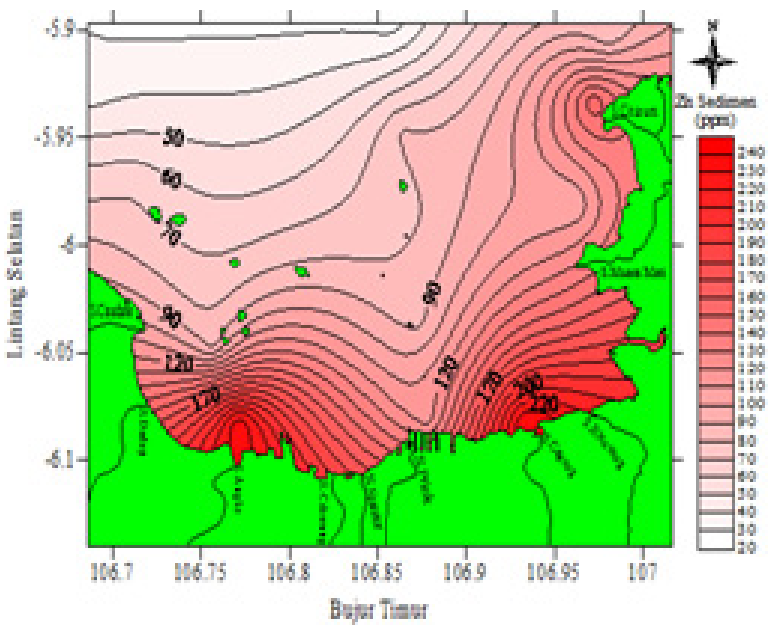

Gambar 15. Sebaran seng (Zn) terendapkan 


\section{KESIMPULAN}

Teluk Jakarta sangat dipengaruhi oleh pasokan dari daratan. Hal ini terlihat dari kondisi fisika-kimia perairan seperti suhu, salinitas, derajat keasaman $(\mathrm{pH})$ dan partikel tersuspensi (TSS). Sebaran logam berat terlarut yang diperkuat dengan sebaran logam berat terendapakan di perairan Teluk Jakarta pada bulan September menujukkan sumber logam berat untuk timbal $(\mathrm{Pb})$, tembaga $(\mathrm{Cu})$ dan seng $(\mathrm{Zn})$ berasal dari daratan sedangkan untuk cadmium $(\mathrm{Cd})$ dan $(\mathrm{Ni})$ berasal dari laut. Sumber logam berat di perairan Teluk Jakarta sebagian besar berasal dari daratan seperti aktivitas pelabuhan dan industri. Sebagian besar sumber logam berat yang berasal dari daratan ini adalah dari aktivitas di pelabuhan seperti pengecetan kapal, pembuangan air ballast, docking kapal dan pengisian bahan bakar mampu memberi kontribusi logam berat ke perairan serta adanya berbagai industri di kawasan pesisir seperti pabrik kimia, cat, tekstil dan batu baterai yang membuang limbahnya melalui sungai atau drainase menuju Teluk Jakarta.

\section{DAFTAR PUSTAKA}

APHA. 2012. Standar Methode For The Examination of Water and Waste Wayer. 22 ${ }^{\text {th }}$ Edition. American Oublic Health Association. USA : Washington DC.

Arifin Z, Susana T, Purwati P, Muchsin $\mathrm{R}$, Hindarti D, Riyono S, Razak $\mathrm{H}$. Matondang A, Salim E dan Farida N. 2003. Ecosystem and productivity of Jakarta Bay and it Summary Report of Competition Research. Jakarta : P20LIPI.

Arifin Z. 2004. Trend of coastal pollution in Jakarta Bay. Indonesia : Its implication for fishery and recreational activities. Di dalam : Rahmawati R, Aldrian E, Hendiarti N dan Tejakusuma I, editor. International Workshop on Coastal Resources Explorattion and Concervation. 2008 Oktober 17-21; Jakarta, Indonesia. Jakarta: BPPT. hlm 16-21.

Arifin Z, Fadhlina D. 2009. Fraksinasi logam berat $\mathrm{Pb}, \mathrm{Cd}, \mathrm{Cu}$ dan $\mathrm{Zn}$ dalam sedimen dan bioavailibitasnya bagi biota di perairan Teluk Jakarta. Ilmu Kelautan. 14 (1):27-32.

Badan Pengendalian Dampak Lingkungan (BAPEDAL). 1993. Laporan Proyek
Pengelolaan dan Pengendalian Pencemaran Lingkungan serta Studi Formasi Pola/Model Pelabuhan Berwawasan Lingkungan. Jakarta: BAPEDAL.

BadanPengelolaanLingkunganHidupDaerah (BPLHD). 2010. Kondisi Lingkungan Hidup dan Kecenderungannya : Status Lingkungan Hidup Daerah Provinsi Daerah Khusus Ibukota Jakarta. Jakarta : BPLHD.

Buffle J, Vitre RR. 1994. Chemical and Biological Regulation of Aquatic System. New York : CRC Press.

Estradivari, Syahrir M, Susilo N, Yusri S Timotius S. 2007. Terumbu Karang Jakarta: Laporan Pengamatan Jangka Panjang Terumbu Karang Kepulauan Seribu. Jakarta : Terangi.

Hadikusumah. 2008. Variabilitas suhu dan salinitas di perairan cisadane. Makara Sains. 12 (2):82-88.

Hamzah F, Setiawan A. 2010. Akumulasi logam berat $\mathrm{Pb}, \mathrm{Cu}$ dan $\mathrm{Zn}$ di hutan mangrove Muara Angke, Jakarta Utara. Ilmu dan Teknologi Kelautan Tropis. 2(2):41-52.

Hutagalung HP. 1994. Heavy Metal in Sediment of Jakarta Bay. Dalam : Prosiding Monitoring Marine Pollution. Hutagalung HP (Ed). P20-LIPI. Jakarta.

Hutagalung HP. 1996. Heavy Metal Cintent in Sediment of Jakarta Bay. In: ASEAN Criteria and Monitoring, Advanced in Marine Enviromental Management and Human Health Protection. Watson D, Ory KS dan Vigers G, editor. ASEANCanada CPMS II. Prosiding and ASEAN-Canada Mediteran Technical Review Conference on Marine Science. Singapura.24-28 Oktober 1996.

Ilahude AG. 1995. Sebaran suhu, salinitas, siqma-T, oksigen dan Zat hara di perairan Teluk Jakarta in Atlas Oseanologi Teluk Jakarta. Jakarta : P20-LIPI.

Ilahude AG, Liasaputra. 1980. Sebaran normal parameter hidrologi di Teluk Jakarta. Jakarta : P2O-LIPI.

Ismail W, Wasilun. 1986. Pengamatan pendahuluan kualitas perairan Kamal Muara. Perikanan Laut. 35:89-94.

Jalius, Setiyanto DD, Sumantadinata K, Riyani E, Ernawati. 2008. Bioakumulasi logam berat dan pengaruhnya terhadap oogenesis kerang hijau (Perna viridis). Riset Akuakultur. 3(1):43-52.

Lestari dan Edward. 2004. Dampak 
pencemaran logam berat terhadap kualitas air laut dan sumber daya perikanan (studi kasus kematian masal ikan-ikan di Teluk Jakarta. Makara Sains. 8 (2):52-58.

Mezuan. 2007. Kajian Kapasitas Asimilasi Perairan Marina Teluk Jakarta [Tesis]. Bogor: Institut Pertanian Bogor.

Muhajir, Edward, Ahmad F. 2004. Akumulasi logam berat $\mathrm{Pb}, \mathrm{Cd}, \mathrm{Cu}, \mathrm{Zn}$ dan $\mathrm{Cr}$ dalam sedimen di Muara Sungai Cisadane, Ciliwung dan Citarum, Teluk Jakarta. Surihi. 3(1):83-98.

Mulyawan I. 2005. Korelasi Kandungan Logam Berat $\mathrm{Hg}, \mathrm{Pb}, \mathrm{Cd}$ dan $\mathrm{Cr}$ Pada Air Laut, Sedimen dan Kerang Hijau (Perna viridis) di Perairan Kamal, Muara, Teluk Jakarta [Tesis]. Bogor: Insitut Pertanian Bogor.

Newyeara JE, Atmojo W, Hariadi. 2014. Sebaran sedimen tersuspensi di perairan Kamal Muara, Penjaringan, Jakarta Utara. Oseanografi. 3(2):210219.

Palar H. 1994. Pencemaran dan Toksikologi Logam Berat. Jakarta : Rineka Cipta.

Paonganan Y, Soedharma D, Nurjaya IW dan Pratono T. 2005. Sebaran spasiotemporal parameter dan kimia perairan bokor, pulau payung dan pulau pari serta di sekitar teluk jakarta. Oseanografi. 8 (20):21-25.

Pemda DKI. 1999. Laporan Neraca Kualitas Lingkungan Daerah DKI Jakarta. Jakarta : Pemda DKI.

Praseno DP, Katoro W. 1979. Laporan Akhir Penelitian Pengembangan Sumberdaya Laut dan Pencemaran Laut. Jakarta : Pusat Penelitian Oseanografi (P20) LIPI.

Razak H. 2004. Laporan Akhir Penelitian Kondisi Lingkungan Perairan Teluk Jakarta dan Sekitarnya. Jakarta :
Pusat Penelitian Oseanografi (P20) LIPI.

Razak H, Muchtar M. 2004. Laporan Akhir: Penelitian Kondisi Lingkungan Perairan Teluk Jakarta dan Sekitarnya. Jakarta : P20- LIPI.

Riyani E. 2010. Kontaminasi merkuri (Hg) dalam organ tubuh ikan pepetek (Leiognathus equulus) di perairan Ancol, Teluk Jakarta. Teknologi Lingkungan. 11(2):313-322.

Rochyatun E, Rozak A. 2007. Pemantauan kadar logam berat dalam sedimen di perairan Teluk Jakarta. Makara Sains. 11(1):28-36.

Sanusi HP, Fitriana M, Haeruddin. 2005. Peranan padatan tersuspensi mereduksi logam $\mathrm{Pb}$ dan $\mathrm{Cd}$ terlarut dalam kolom air Teluk Jakarta. Ilmu Kelautan. 10(3):165-168.

Simanjuntak M. Kadar fosfat, nitratdan silikat di Teluk Jakarta. Perikanan. 9(2):274-287.

Sutisna. 2007. Analisis beban pencemaran dan kapasitas asimilasi kawasan Perairan Pelabuhan Sunda Kelapa Jakarta. [Tesis]. Bogor: Institut Pertanian Bogor.

Wardianto Y, Damar A, Sumartono B. 2004 Ashort riview on the recent problem of red tide in Jakarta Bay: Efectof red tide on fish and human. Ilmu Perairan dan Perikanan Indonesia. 11(1):66-71.

Williams TM, Ress JG, Setiapermana D. 2000. Metal and trace organic compounds in sedimen and waters of Jakarta Bay and the pulau seribu complex, Indonesia. Marine Pollution Bulletin. 40(3):277-285.

Yatim S, Surtipanti S, Suvirma, Lubis E. 1979. Distribution of heavy metal in water of Jakarta Bay. Majalah Batan. 8(3):1-19. 
